\title{
Strategy of Insan Kamil in Building Green Education
}

\author{
Nurti Budiyanti' ${ }^{1}$ Asep Abdul Aziz ${ }^{2}$, Mohamad Erihadiana ${ }^{2}$ \\ 1 Universitas Pendidikan Indonesia, Indonesia \\ 2 Universitas Islam Negeri Gunung Djati Bandung, Indonesia
}

Corresponding Author: Nurti Budiyanti, nurtibudiyanti@upi.edu

\begin{tabular}{|c|c|}
\hline \multirow[b]{2}{*}{$\begin{array}{l}\text { ARTICLE INFO } \\
\text { Article history: } \\
\text { Received } \\
\text { June 23, } 2020 \\
\text { Revised } \\
\text { June 29, } 2020 \\
\text { Accepted } \\
\text { July 18, } 2020\end{array}$} & ABSTRACT \\
\hline & $\begin{array}{l}\text { The reality of life illustrates the low level of human concern on } \\
\text { environment. In fact, it undeniably promotes environmental damage } \\
\text { nationally and globally. Therefore, the ecosystem damage in various } \\
\text { places and regions has become a serious threat to the survival of the life of } \\
\text { the universe. Humans are closely related to nature and they have a great } \\
\text { responsibility to protect the universe. In regard to this issue. This article } \\
\text { provides an overview of the ideal human strategy, namely Insan Kamil, as } \\
\text { a means of increasing awareness of our status as 'Abdun and our role as } \\
\text { caliph in instilling awareness of environmental love through Green } \\
\text { Education. This study employed a qualitative approach in the form of } \\
\text { literature study in collecting data. The result found that Insan Kamil is } \\
\text { considered as a human who is trying to realize his status as a servant of } \\
\text { Allah and his role as khalifatullah who has a Divine vision to worship } \\
\text { Allah and they also have mission in maintaining natural order and } \\
\text { prosperity of the environment. Through the approach of spiritual } \\
\text { education, its strategy must be applied within family, school, and } \\
\text { community. Thus, it is clear that the strategy of this Insan Kamil is not only } \\
\text { in the scope of formal education, but non-formal and in-formal education } \\
\text { must also have the same objective integration in order to foster awareness } \\
\text { of environmental love through Green Education. }\end{array}$ \\
\hline & Keywords: Strategy of Insan Kamil, Green Educaiton \\
\hline How to cite & $\begin{array}{l}\text { Budiyanti. N., Aziz, A., \& Erihadiana, M. (2020). Strategy of Insan Kamil in } \\
\text { Building Green Education. IJoASER (International Journal on Advanced Science, } \\
\text { Education, and Religion), 3(2). 72-82. https://doi.org/10.33648/ijoaser.v3i2.54 }\end{array}$ \\
\hline Journal Homepage & https://ojs.staialfurqan.ac.id/IJoASER/ \\
\hline Published by & STAI Al-Furqan Makassar \\
\hline
\end{tabular}

\section{INTRODUCTION}

Today, life illustrates how far humans are care about the environment. Hence, environmental issues return to the spotlight of the world, based on data from the Indonesian environmentalists association, regarding environmental issues locally (Rebolledo et al., 2016; May et al., 2019; May, Kleyn , \& Vekovshinina, 2019). The result research reported that the depletion of the ozone layer is often discussed. Without the ozone layer, there will be many negative impacts that will befall living creatures on this earth such as, the disease spread out of control, erratic weather, global warming, drought, floods, landslides, and even sinking of a land due to rising sea levels caused melting of ice in the North Pole and South Pole (Toman, 2017; Manning \& Nobles, 2017; Ren et al., 2019). While nationally. we encounter issues about forest fires, oil pollution, floods, forest destruction in Indonesia, uncontrolled waste. As for globally, many are influenced by natural factors, such as climate, rainfall, humidity, air pressure to global warming (Nuha, 2017; Harvey, 2018). Global warming results in an increase 
in the surface temperature of the earth which affects extreme climate change on earth (Hidayat \& Sciences, 2015; Dai et al., 2015; Thirumalai et al., 2017).

Various environmental damage that feel turned out to have a major adverse impact on today's life. Almost all ecosystems are threatened by damage and degradation caused by humans. But the main concern is the loss of some ecosystems that play an important role in the evolutionary process (Fugiel et al., 2017; Siswanto, 2008; Almeida et al., 2017). Therefore, The damage to ecosystems in various places and regions has become a serious threat to the survival of humanity (Rochwulaningsih, 2017; Karlsson et al., 2017). Today's ecosystem is a new ecosystem created by human civilization to adapt to human needs. With science and technology, the ability of humans to change the environment is greater, so that human desire to dominate nature emerges. Nature which was originally still able to maintain balance now lost. There is damage everywhere, because of human activities. Because it can be said that humans are environmentally destructive creatures on earth. The environment in general is defined as everything that is outside of human beings related to human life. In this case, environmental studies are included in the scope of natural studies, which from the first philosophy was born and from this the science and technology developed (Hidayat \& Ilmu, 2015). Humans are an inseparable part of nature. Human existence in nature is interdependent, interrelated with other creatures. Humans in addition to having a role as part or component of nature, humans have a special role and position between the natural components and other creatures created by God, namely 'Abdun and the Caliph. Humans have three relations to the surrounding environment, namely the relationship of faith and worship; relationship of utilization and sustainability; and maintenance relations for all beings (Nasution, Sinaga, \& Salminawati, 2019). But ironically, the harmonious relationship between humans and their environment has not been able to materialize optimally.

Many previous studies who discussed that the process of planting awareness of environmental love needs to be supported by the development of activities in educational institutions (Nurulloh, 2019; Ridhwan \& Wardhana, 2019), especially in instilling Islamic values (Obaid, 2013). But there is no appropriate strategy in developing the concept of environmental love in education practitioners comprehensively. There is a need to strengthen the strategy undertaken by Muslims in overcoming environmental damage, especially in educational institutions. One of them is to make as much awareness as possible related to our status as ' Abdun and our role as caliph, in order to form a perfect human being, or we are known as Insan Kamil who certainly has a special strategy based on Islamic studies in building environmental awareness in the world of education, which came to be known as Green Education. The concept of greening is a form of pious practice that contains many benefits and contains many benefits in realizing the order of the universe and prosperity of the environment. This study aims to obtain a formula regarding the strategy of Insan Kamil in building Green Education in an effort to increase awareness of environmental love as a form of obedience to God.

\section{METHODS}

The design of this study used a qualitative approach, with non-interactive methods (document analysis) (Hite et al., 2018). In qualitative research the instrument or research tool is the researcher himself. Researchers collected data from various literary sources in the form of documents such as books, journals, seminar results, and discussions with experts relevant to the research theme. The steps of analysis carried 
out in this study are based on the steps of data analysis according to Sugiyono (2011), which are as follows: (a) Data Reduction : summarizes, chooses the main points, and focuses the data on things the important one. (b) Data Display : in the form of a description, then tables and charts, in order to facilitate the reader to understand the contents of the research study. (c)Conclusion Drawing (Verification): draw conclusions and provide an interpretation of the formulation of the strategy Insan Kamil in order to foster awareness of environmental love through Green Education.

\section{RESULT AND DISCUSSION}

The concept of a perfect and ideal human being (Insan Kamil) in Islam is a quite interesting study and very important for us to know. Insan Kamil is a harmony of two forms in humans. The first form is the existence of perfection in terms of form which includes all the devices that exist in humans. Such perfection is a gift from Allah. and is also the result of manifestation of the ability to guard against all forms that can injure and endanger themselves and the ability to use them. While the second is the perfection of knowledge. The perfection of this knowledge is based on the curiosity to gain knowledge. Curiosity and even then requires humans to be able to use or use the potential that exists in him to gain as much knowledge (Harahap \& Siregar, 2017). For this reason, humans are called Insan Kamil.

Insan Kamil is the ideal human being with the highest degree compared to other creatures. His role as the caliph of Allah Most High as the leader of the world, keeps the world safe, peaceful and orderly. Insan Kamil is not only someone who is physically perfect, but someone who is perfect in his knowledge. Like the concept of Insan Kamil developed by Suhrawardi. The knowledge of a Kamil Individual is different from that of ordinary people, because Insan Kamil obtains knowledge from the source of knowledge itself. According Suhrawardi someone who has combined intellectual power (rational) and intuition power, so that the person gains knowledge then that person can be said to be a Insan Kamil (Budiyanti et al., 2016). In his view too, Insan Kamil is a philosopher not only someone who has rational knowledge, but at the same time becomes a saint, someone who is enlightened in Ilāhi's knowledge (Dewi, 2015).

Meanwhile, the concept of perfect human beings as written by Soejono Redjo in (Saudah \& Nusyirwan, 2007) shows the explanation of a perfect human being, a selfforgetful man, immersed in the devotion to worship following the rules of God. As other experts call it a superior human being. Someone who has a superior personality will be clearly reflected in his faith through the deeds of deeds in his daily life (Nurrahman, 2015). By returning to his natural state, and to the reality of himself as a faithful servant of Allah, aware of his role as khalifatullah (Subhi, 2014; Idris, 2017; Setiawan, 2020). That means, the position of Insan Kamil is very necessary to regulate the universe.

Humans essentially have an inherent tendency in themselves to achieve something that is morally believed to be good. In other words it is said that humans are always on an eschatological journey towards the virtues of morality. Morality, then, is used as a measure of human perfection. Therefore, morality is the most central problem in all religions (Nasution, 2011; Parhan et al., 2020). In the teachings of Islam to foster moral values known as spiritual values. To be able to present spiritual values, it is necessary to raise awareness of ilähiyyah to draw closer to God (Sodiman, 2014).

To increase spiritual value, there are steps and efforts that must be done by someone, namely tazkiyatu al-nafs, mujähadah, and riyadhah. For someone who will lead the life of Sufism must take the maqam (spiritual stages), namely repentance, zuhud, 
faqir, patience, trust and sincerity. For someone who is undergoing Sufism, after taking maqam (spiritual position or stage), then he will feel the spiritual condition that is muraqabah, qurbah, muhabbah, khauf, raja ', syauq, uns and musyaadah (Fahrudin, 2016). To achieve this, it requires several processes that must be passed first, namely the process of takhali (emptying the heart of the despicable nature), tahali (filling the heart of the praiseworthy nature), and tajali (self-approach to God) (Setiawan, 2020). This stage will lead man to become the ideal human being expected by God.

There are many Islamic scientists who describe the ideal human characteristics expected by the Go. Khulaisie (2016) who formulated 10 ideal human characteristics that must be formed in the world of education, namely: (1 ) Salimu al-Aqidah : with aqidah that is clean, a Muslim will have a strong bond to Allah. (2) Sahihu al-Ibādah: true worship is one of the important commands of the Prophet Muhammad and must not have an element of addition or subtraction. (3) Maținu al-Khulūq: noble character is an attitude and behavior that must be possessed by every Muslim, both in relation to God, to God's creatures, and the natural environment. (4) Qawiyyu al-Jismi : physical strength means that a Muslim has endurance so that he can carry out Islamic teachings optimally with his strong physique. (5) Musaqqaf al-Fikriaspects : intellect in thinking is one of the importantof the Muslim person, with the power of human thinking to overcome various problems that exist. (6) Mujähadah Li Nafsihi : striving against lust is one of the personalities that must be present in a Muslim, in order to always increase faith. (7) Harișun Alā Waqtihi : good at maintaining time is an important factor for humans in valuing every activity carried out by humans. (8) Munaz amunFì Syūnihi : organized in a matter both related to the ubudiyah and muamalah problems. (9) Qadìrun Alä al-Kasbi : has the ability of his own efforts to defend and uphold the truth. (10) Nafi'un Li Ghairihi : beneficial for others, including providing benefits to God's creatures and the natural environment.

These characteristics must be attached to the ideal human attitude in influencing life. Islam's view of humans is more comprehensive which Allah has created as a perfect and noble creature to manage the earth and its contents. Therefore all psychological forms and mental health on earth must be in accordance with what is taught by Allah SWT in His religion, such as filtered and adjusted to the principles, goals and rules contained in Islamic law (Amir, 2012). Of course, by developing the potential that humans have. Human potential in the view of Islam of various types, in the form of nature, spirit and heart is good. While the potential in the form of reason is neutral and in the form of lust and body are bad (Khobir, 2010). Meanwhile, the meaning of fitrah in the Koran can be grouped in at least four meanings: (1) The process of creating heaven and earth. (2) The process of human creation. (3) The order of the universe and its contents are harmonious and balanced. (4) Meaning in the religion of God as a basic reference and guide for humans in carrying out their duties and functions (Nizar, 2001).

This explanation confirms that humans are naturally obliged to take care of the universe in accordance with the rules that God wants. Nature and life are human environment in the universe system. With a certain value and norm system, humans can change nature into a source of life that is positive (benefit) or negative (harm), which then has an impact on life. The impact of benefits will bring humans to happiness, welfare and glory, while the impact of harm can cause the destruction of human life itself. With full strong attachment to the divine value system, humans will not tend to be anthropocentric (Ilyas, 2008). This means that if he does something to maintain, preserve, develop and improve the quality of his life, it is not only directed 
towards human beings themselves. Such a human being will always remember (dhikr) Allah while standing, sitting or lying and thinking (thinking) about the creation of heaven and earth. And finally he feels a sense of responsibility to always improve the quality of his life well. With the presence of a full sense of responsibility, people can build awareness of environmental love through Green Education. The author presents a chart of the responsibilities of Insan Kamil in developing Green Education as follows:

Figure 1. Responsibilities of Insan Kamil in developing Green Education

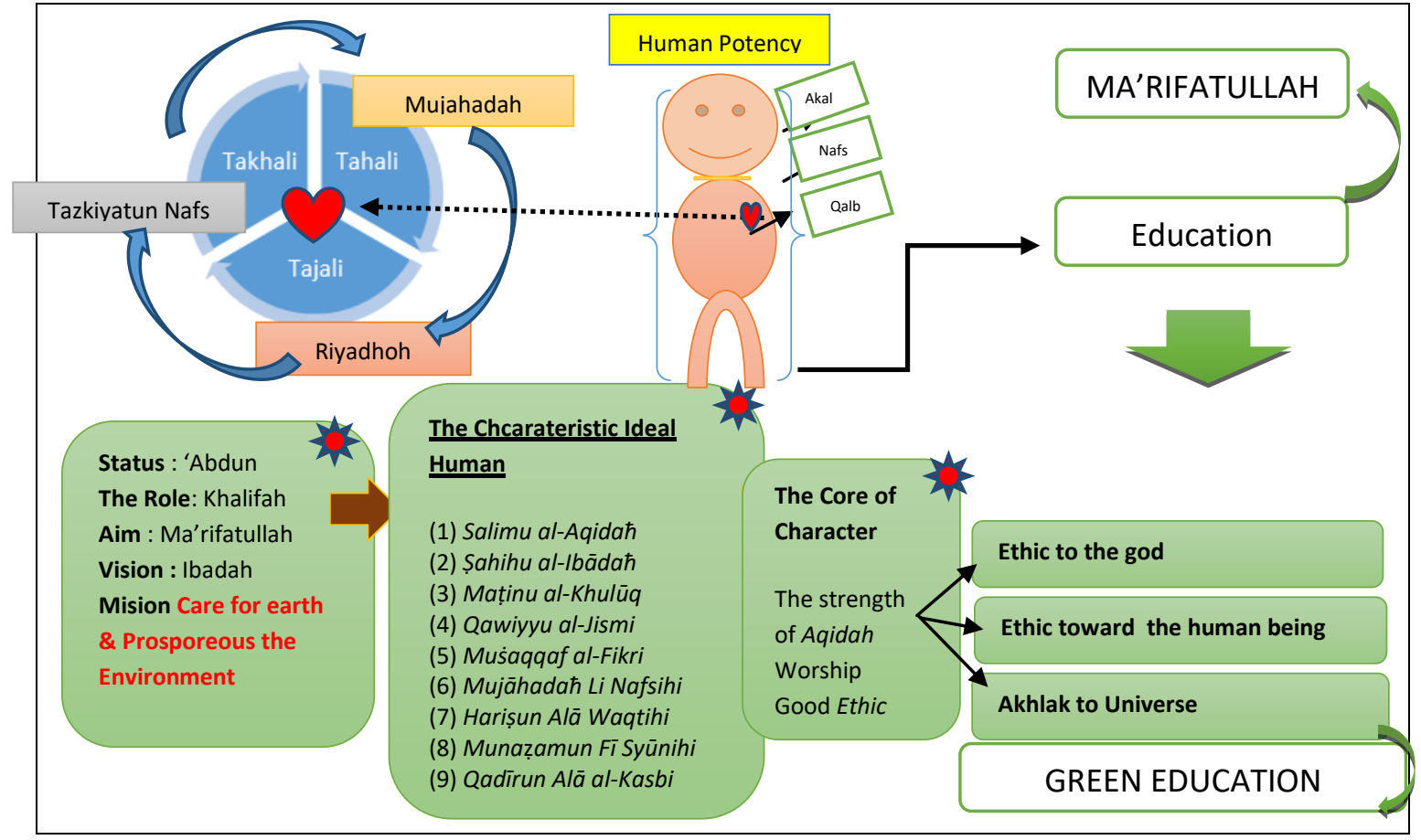

The figure discussed that humans have the potential in the form of reason, nafs and qalb. This potential needs to be developed through education in order to grow intellectual intelligence, emotional intelligence, and spiritual intelligence. Education in Islam is an effort to raise human status as a servant of Allah and his role as khalifatullah, as well as the process of developing, strengthening and actualizing all potentials possessed in daily life in order to reach ma'rifatullah. With the aim of perfecting faith, piety, and morals, as well as actively building a nation's civilization that is dignified with ma'rifatullah (Rizal, 2014). So that humans have a vision divine that is worshiping God (Mufid, 2010), and has a mission to maintain the order of nature. In order to maintain this natural order, humans must strive to love the natural environment, one of them is by building Green Education.

In Indonesian, Education can be interpreted as education or education. According to Law No. 20 of 2003, education is a conscious and planned effort to create an atmosphere of learning and learning process so that students actively develop their potential to have spiritual spiritual strength, self-control, personality, intelligence, noble character, and the skills needed by themselves, the community, the nation, and country (Shima, 2016). So, Green Education is an effort to realize learning activities in shaping the personality of students who are aware and love the environment, understand the concept of environmentally friendly, and master the environmentally friendly culture of living. 
Yusuf Qardhawi in (Syafrilsyah \& Fitriani, 2016) asserted that the ideal man must be able to protect the environment due to five reasons, namely: (1) Reconstruction of the meaning of the caliph. In the Qur'an it is emphasized that becoming a caliph on this earth is not to do destruction and bloodshed, but to regulate the balance of nature by applying Allah's rules. (2) Ecology as a teaching doctrine. That is, placing environmental discourse in the main doctrine (usul) of Islamic teachings. (3) One's faith is imperfect if it doesn't care about the environment. A person's faith is not only measured by the number of rituals in a place of worship. But, also protecting and preserving the environment is very fundamental in the perfection of one's faith. (4) Environmental destroyer is an ecological infidel (kufr al-bi'ah). Among the signs of the greatness of God is the existence of this universe (universe). For this reason, damaging the environment is the same as denying (infidels) the greatness of God (favor of Allah), as in Qs. Shaad paragraph 27. (5) Fight for green politics (green politics), a movement to accompany development in order to have an ecological perspective. Anti-ecological, mechanistic, and materialistic political policies are directed towards ecological political policies. This is important because natural damage that is so severe can not only be solved through a religious approach. However, a comprehensive approach is needed. Starting from religion, economy, politics, culture, and social unite in handling this ecological crisis. Religion becomes the main center as the basis for developing awareness of environmental love, so that it can lead to environmental prosperity. The environment is a system that is a unity of space with all objects, power, conditions, and living things, including human beings and their behavior that affect the continuity of life and human well-being and others.

Management of the environment is the utilization and improvement of the quality of the environment which is charged to humans because Allah created mankind from the earth and make humans their prosperity. The mandate of God placed upon humans is to prosper this earth with prosperity that encompasses all fields, establishes a healthy human society and fosters a comprehensive human civilization, encompassing all aspects of life so as to realize divine justice on earth without coercion and violence, but with lessons and one's own awareness (Ilyas, 2008). Approaches that we can take in managing the environment include the development of reliable human resources, sustainable development of the environment, and returning to the guidance of Allah SWT and His Messenger in environmental management. The requirements for reliable HR include HR aware of the environment and holistic view, legal awareness, and commitment to the environment (Nuha, 2017). In addition, every HR needs to have the right technical skills and scientific knowledge to go green, but this alone is not enough. Individuals must be willing to reduce behavior that is less environmentally friendly (Yusup, Kistiono, \& Ariska, 2013).

There are several factors that influence people's unconsciousness towards the environment, namely ignorance, poverty, humanity, and lifestyle factors (Manganjaya, 2006). There needs to be an effort to conserve the environment in raising awareness, themovement Go Green Indonesiahas launched a number of significant programs namely: (1) Movement to plant Trees. (2) Voice and encourage all elements of the community to succeed in the Green Campaign. (3) Making efficient use of electrical energy, reducing the use of fuel oil and coal. (4) Reducing the use of paper. (5) Efficient and reduce water use. (6) Make changes to green lifestyles that are environmentally friendly by using and buying products that are environmentally friendly. (7) Repairing electronic devices so they do not become waste or rubbish. (8) Commit to continuing to 
voice and promote Go Green Indonesia that is greener and cleaner. (9) Promote forest, river and sea improvement programs to be clean of rubbish (Nuha, 2017).

Thus, we should not do illegal deforestation, littering, air pollution, excessive use of crops, and immoral behavior. It is necessary to have a strategy carried out by Muslims as a generation of Insan Kamil in dealing with such problems. The author presents the ideal human strategy chart (Insan Kamil) in building Green Education:

Figure 2. Strategy of Insan Kamil dalam in Building Green Education

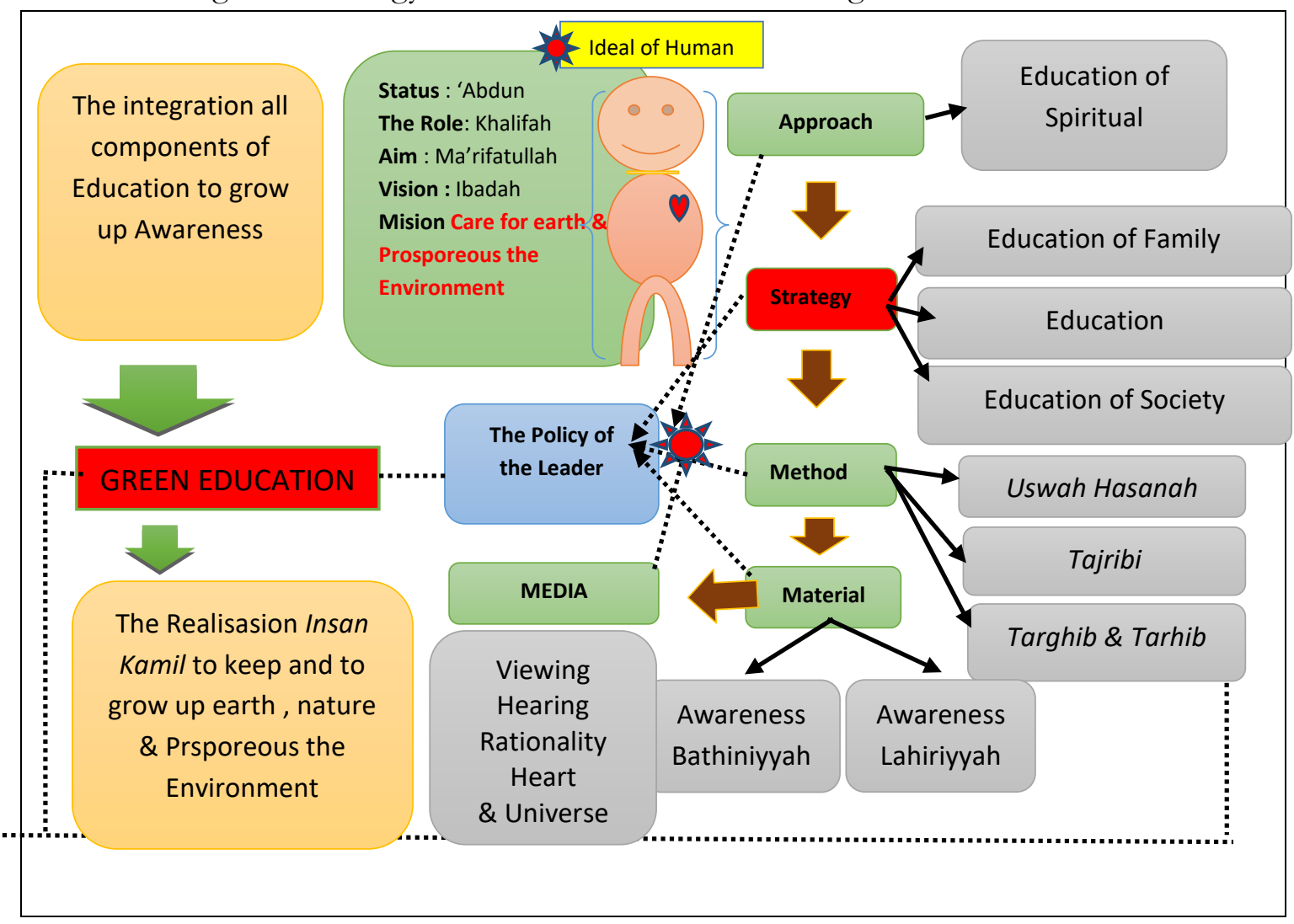

The finding reported Insan Kamil is the best generation that applies Islamic values, he is able to do various prevention of natural damage, either outwardly or spiritually. Because the strength of his faith pushes to optimize his ability to maintain the natural environment optimally, being aware of its status as'Abdun and his role as caliph. Hence, the actualization of this consciousness as a form of obedience to God, carry out the mandate to preserve, maintain and manage nature well. Commensurate with various other studies, that awareness is the beginning that can determine a person's step forward in building Green Education (Halid et al., 2014, Nurulloh, 2019). Sumarni (2008) revealed in her research that building a Green Education needed a special approach, the approach that was deemed appropriate was to use a contextual approach. However, Those findings were different, because the current research used a spiritual approach. Spiritual approach is the right choice that will have an impact on the level of awareness in practicing Islamic values. With a spiritual approach there will be a path of divine educational communication whereby the values of monotheism become the basis for developing thought patterns which will certainly have an impact on life activities. 
Through the approach of spiritual education, it is expected that humans have awareness both in lahiriyyah and in physical consciousness. The strategy that can be done in applying awareness of environmental love is to apply a spiritual approach to three interrelated realms, namely in the family, school and community. So, it has implications for other educational practices such as methods, media and materials. The methods that can applied involving: 1) the use of the method. That is uswah which is to set an example of environmental love, (2) the method of tajribi, habit of namely the doing environmentally friendly activities and (3) the method targhib-tarhib that is reward and punishment, giving rewards and reprimands on every behavior which is done in the learning process. These various methods can strengthen the material that would be delivered to others, where the material presented must contain Islamic values in order to increase awareness in lahiriyyah and bathiniyyah. Meanwhile, the media that can be used are the media of the five senses and the universe, by always deceiving vision, hearing, mind and heart to study the greatness of the Divine.

Thus in the concept of environmentally friendly, humans are not only aware of the importance of health and cleanliness, but humans must also be aware of the importance of carrying out the mandate as a caliph to maintain the order of the universe, as the actualization of spiritual education attached to him, which of course this would be influenced by the policy of a leader, be a family leader, school leader or community leader. The Strategy is not only in the scope of formal education, but nonformal and in-formal education must have the same integration of goals in order to foster awareness of environmental love through Green Education.

\section{CONCLUSIONS}

Humans have the potential in the form of reason, nafs and qalb. This potential needs to be developed through education in order to grow intellectual intelligence, emotional intelligence, and spiritual intelligence. Humans have a goal that is perfecting faith, piety, and morals, as well as actively building a nation's civilization that is dignified with ma'rifatullah. So that humans have avision divine that is worshiping God, with its mission to maintain the order and nature of the environment. Through the approach of spiritual education, it is expected that humans have awareness both in lahiriyyah and in physical consciousness. The strategy is to apply awareness of environmental love in three interrelated domains, namely in the family, school and community environment. The method that we can apply is to use the uswah method, which is to set an example of environmental love, the tajribi method, which is to carry out environmentally friendly activities and the targhibarbhib method, namely reward and punishment, to reward and reprimand every behavior we do.

\section{ACKNOWLEDGEMENTS}

Thank you for participant in this research and teacher for help in this research. Thank also for the Team IJoASER Journal who give suggestion, coment review and guiding review process. Hence, manuscript can be published in this journal.

\section{AUTHOR CONTRIBUTION STATEMENTS}

Nurti Budiyanti (NB) was the first author who analysing the data. Asep Abdul Aziz (AAZ) as the second author who help collecting the data. While, the third author was Mohamad Erihadiana (ME) that helps some revisions in this journal. 


\section{REFERENCES}

Almeida, T. A. das N., Cruz, L., Barata, E., \& García-Sánchez, I.-M. (2017). Economic growth and environmental impacts: An analysis based on a composite index of environmental damage. Ecological Indicators, 76, 119-130. https:// doi.org/10.1016/j.ecolind.2016.12.028

Amir, D. (2012). Konsep Manusia Dalam Sistem Pendidikan Islam. Al-Ta Lim, 19(3), 188. https:// doi.org/10.15548/jt.v19i3.52

Budiyanti, N., Rizal, AS, \& Sumarna, E. (2016). Implikasi konsep ūlūl 'ilmi dalam alqur`ān terhadap teori pendidikan islam (studi analisis terhadap sepuluh tafsīr mu'tabarah). tarbawy: Indonesian Journal of Islamic Education. https://doi.org/10.17509/t.v3i1.3459

Dai, A., Fyfe, J. C., Xie, S.-P., \& Dai, X. (2015). Decadal modulation of global surface temperature by internal climate variability. Nature Climate Change, 5(6), 555-559. https://doi.org/10.1038/nclimate2605

Dewi, E. (2015). Konsep Manusia Ideal dalam Persepektif Suhrawardi Al-Maqtul. Substantia, 17(1), 41-54. http:/ / dx.doi.org/10.22373/subtantia.v17i1.4107

Fahrudin. (2016). Tasawuf sebagai upaya bembersihkan hati guna mencapai kedekatan dengan allah. Jurnal Pendidikan Agama Islam Ta'lim, 1(1), 65-83. Google Scholar

Fugiel, A., Burchart-Korol, D., Czaplicka-Kolarz, K., \& Smoliński, A. (2017). Environmental impact and damage categories caused by air pollution emissions from mining and quarrying sectors of European countries. Journal of Cleaner Production, 143, 159-168. https:/ / doi.org/10.1016/j.jclepro.2016.12.136

Harvey, L. D. D. (2018). Global Warming. Routledge.

Harahap, M., \& Siregar, LM (2017). Konsep Pendidikan Islam Dalam Membentuk Manusia Paripurna. Jurnal Pendidikan Agama Islam Al-Thariqah, 2(2), 148. https:// doi.org/10.25299/althariqah.2017.vol2(2).1040

Halid, I., Setyono, P., \& Sunarto. (2014). Implementasi Nilai-Nilai Islam Dalam Sikap Ramah Lingkungan Untuk Pndok Pesantren (Studi Kasus Di Pondok Pesantren Nurul Haramain Nw Narmada Dan Pondok Pesantren Nurul Hakim Kediri Lombok Barat ). Ekosains, VI(1), 24-32. Google Scholar

Hidayat, A., \& Ilmu, F. (2015). Pendidikan Islam dan Lingkungan Hidup. Jurnal Pendidikan Islam IV(2), 373-389. Google Scholar

Hite, R., Solís, P., Wargo, L., \& Larsen, T. B. (2018). Exploring Affective Dimensions of Authentic Geographic Education Using a Qualitative Document Analysis of Students' YouthMappers Blogs. Education Sciences, 8(4), 173. https:// doi.org/10.3390/educsci8040173

Idris, S. (2017). Insan Kamil : Theological and Psychological Perspectives. Asian Journal of Social Sciences, Arts and Humanities, 5(2), 9-28. Google Scholar

Ilyas, MM (2008). Lingkungan Hidup dalam Pandangan Islam, Jsh Jsh:Jurnal Sosial humaniora, 1(2), 154-166. http:// dx.doi.org/10.12962/j24433527.v1i2.672

Karlsson, P. E., Klingberg, J., Engardt, M., Andersson, C., Langner, J., Karlsson, G. P., \& Pleijel, H. (2017). Past, present and future concentrations of ground-level ozone and potential impacts on ecosystems and human health in northern Europe. Science of The Total Environment, 576, 22-35. https:/ / doi.org/10.1016/j.scitotenv.2016.10.061

Khobir, A. (nd). dalam proses pendidikan (Tinjauan Filsafat Pendidikan Islam ). 1-15.

Khulaisie, RN (2016). Hakikat Kepribadian Muslim, Seri Pemahaman Jiwa Terhadap Konsep Insan Kamil. Jurnal Refletika. http:/ / dx.doi.org/10.28944/reflektika.v11i1.36 
Little, JT (1987). al-insān al-kāmil: the perfect man according to ibn al-'arab? the muslim world. https:/ / doi.org/10.1111/j.1478-1913.1987.tb02785.x

Manning, S. R., \& Nobles, D. R. (2017). Impact of global warming on water toxicity: cyanotoxins. Current Opinion in Food Science, 18, 14-20. https://doi.org/10.1016/j.cofs.2017.09.013

May, I. V., Kleyn, S. V., \& Vekovshinina, S. A. (2019). Assessment of impact of accumulated environmental damage to the quality of soil, surface and groundwater, agricultural products resulted from the mining enterprise. IOP Conference Series: Earth and Environmental Science, 315, 062024. https:// doi.org/10.1088/1755-1315/315/6/062024

Nurrahman. (2015). Konsep Manusia Unggul: Kajian atas Naskah Anis Al-Muttaqin. Jurnal Lektur Keagamaan, 11(1), 181-202. Google Scholar

Nurulloh, ES (2019). Pendidikan Islam dan Pengembangan Kesadaran Lingkungan. $\begin{array}{llll}\text { Jurnal Penelitian Pendidikan } & 237 .\end{array}$ https://doi.org/10.36667/jppi.v7i2.366

Obaid, MY (2013). Religiusitas Lembaga Pendidikan yang Berwawasan Lingkungan. Jurnal Al-Ta' dib, 6(1), 137-149. Google Scholar

Parhan, M., Faiz, A., Karim, A., Nugraha, RH, Subakti, GE, Rindu, M., Islamy, F., Budiyanti, N., Fuadin, A., \& Tantowi, YA (2020). Internalization Values of Islamic Education at. International Journal of Psychosocial Rehabilitation, 24(08), 14778-14791. https:/ / doi.org/10.37200/IJPR/V24I8/PR281455

Rebolledo, B., Gil, A., Flotats, X., \& Sánchez, J. Á. (2016). Assessment of groundwater vulnerability to nitrates from agricultural sources using a GIS-compatible logic multicriteria model. Journal of Environmental Management, 171, 70-80. https:/ / doi.org/10.1016/j.jenvman.2016.01.041

Ren, J., Wang, X., Gong, P., \& Wang, C. (2019). Characterization of Tibetan Soil As a Source or Sink of Atmospheric Persistent Organic Pollutants: Seasonal Shift and Impact of Global Warming. Environmental Science \& Technology, 53(7), 3589_ 3598. https://doi.org/10.1021/acs.est.9b00698

Ridhwan, R., \& Wardhana, W. (2019). Pendidikan Islam Berwawasan Lingkungan Hidup Pada Madrasah Ibtidaiyah Di Bone Sulawesi Selatan. Jurnal MUDARRISUNA: Media Kajian Pendidikan Agama Islam, 9(1), 77-96. https:// doi.org/10.22373/jm.v9i1.4844

Rizal, AS (2014). filsafat pendidikan islam islami oleh: ahmad syamsu rizal a . pendahuluan pendidikan baik pada tataran teoritis maupun praktis . Ia dapat merupakan aplikasi. Jurnal Pendidikan Agama Islam - Ta'lim, 12(1), 1-18. Google Scholar

Rochwulaningsih, Y. (2017). Dinamika Gerakan Lingkungan dan Global Environmental Governance. Jurnal Sejarah Citra Lekha, 2(2), 151-160. https:// doi.org/10.14710/jscl.v2i2.16188

Saudah, S., \& Nusyirwan. (2007). Konsep Manusia Sempurna. Jurnal Filsafat, 14(2), 185191. https:/ / doi.org/10.22146/jf.31332

Setiawan, W. (2020, March). The spiritual education toward insan kamil in the education of modern humankind. In international seminar on education (pp. 478-483). Google Scholar

Shima, R. D., Wimala, M., \& Akmalah, E. (2016). Kajian Kategori Education pada Pelaksanaan Green Campus di Itenas (Hal. 105-114). RekaRacana: Jurnal Teknil Sipil, 2(3), 105. https:/ / doi.org/10.26760/ rekaracana.v2i3.105

Sodiman, S. (2014). Menghadirkan Nilai-nilai Spiritual Tasawuf Dalam Proses 
Mendidik. Al-Ta'dib, 7(2), 37-59. Google Scholar

Subhi, M. (2014). Doktrin Manusia Universal dalam Antropologi Metafisis Seyyed Hossein Nasr. Jurnal Universitas Paramadina, 11(3), 1128-1145. Google Scholar

Sugiono. (2011). metode penelitian pendidikan (pendekatan kuwantitatif,kuwalitatif,R\&D). In Alfabbeta Pres.

Sumarni. (2008). Sekolah hijau sebagai alternatif pendidikan lingkungan hidup dengan menggunakan pendekatan kontekstual. Jurnal Ilmu Pendidikan 15(1), 19-25. Google Scholar

Thirumalai, K., DiNezio, P. N., Okumura, Y., \& Deser, C. (2017). Extreme temperatures in Southeast Asia caused by El Niño and worsened by global warming. Nature Communications, 8(1), 15531. https:/ / doi.org/10.1038/ncomms15531

Toman, M. A. (2017). Climate Change. Routledge. 